\title{
Cytogenetic and molecular findings in patients with Turner's syndrome stigmata
}

T Kuznetzova, A Baranov, N Schwed, T Ivaschenko, P Malet, M Giollant, G A Savitsky, V Baranov

\begin{abstract}
Cytogenetic and DNA analysis in 12 people with stigmata of Turner's syndrome was carried out. Cytogenetic analysis of these patients showed two subjects with $46, X$, i(Xq) karyotypes, one with $45, X / 46, X$, $i(X q)$, one with $46, X, t(X ; Y)$, and eight with $45, X / 46, X$,mar. Molecular analysis of DNA samples was performed in nine out of 12 patients with marker chromosomes. PCR analysis with oligoprimers specific for SRY, DYZ1, or DYZ3 loci identified $Y$ chromosome material in five patients in the latter group. The $\mathrm{X}$ chromosome origin of the marker chromosome was proved by FISH technique with biotin labelled pericentromeric $X$ chromosome specific probe in four other patients. These results show that patients with a number of Turner's syndrome stigmata usually do not have a typical XO karyotype but have some structural chromosomal aberrations involving the $X$ or $Y$ chromosomes. Combined application of cytogenetic, molecular cytogenetic (FISH), and PCR techniques significantly improves the precision of marker chromosome identification and thus might be of practical importance for the proper management and treatment of affected patients.

Peculiarities of pathological manifestations of different karyotypes bearing structural abnormalities of the $X$ or $Y$ chromosomes in patients with Turner's syndrome stigmata, as well as feasible genetic mechanisms of sex determination and differentiation abnormalities in these subjects, are briefly discussed.
\end{abstract}

(f Med Genet 1995;32:962-967)

Institute of Obstetrics and Gynaecology,

Mendeleevskaya line 3 St Petersburg 199034, Russia

T Kuznetzova

A Baranov

A Barano

T Ivaschenko

G A Savitsky

V Baranov

Centre Hospitalier

Universitaire,

Clermont-Ferrand,

France

P Malet

M Giollant

Correspondence to: Professor V Baranov.

Received 8 March 1995 Revised version accepted for publication 11 July 1995

According to recent reports only about half of all Turner's syndrome patients are really monosomic for the whole $\mathrm{X}$ chromosome, while the other half is represented by a heterogeneous group with different structural abnormalities of the sex chromosomes. ${ }^{1}$ Most of them are confined to structural rearrangements of the $\mathrm{X}$ chromosome. The other group of these patients have a mosaic karyotype with the second cell lines carrying numerical or structural sex chromosomes anomalies. ${ }^{1} \mathrm{De}-$ tailed clinical and cytogenetic analysis of these patients can provide new information on the developmental effects of different chromosomal segments and their participation in normal and abnormal development. De- velopmental cytogenetics has already been quite thoroughly elaborated in mice $^{2}$ but still remains in its infancy in humans.

Complex comparative clinical, cytogenetic, and molecular analysis is also important to determine the nature of marker chromosomes because of the high risk of malignancy in dysgenetic gonads owing to the presence of $\mathrm{Y}$ chromosome material. ${ }^{34}$

Mosaic karyotypes with small marker chromosomes represent a difficult task for cytogenetic analysis by routine classical methods. However, the combination of cytogenetic and molecular techniques enables this problem to be solved quite efficiently and the origin of markers in patients with Turner's syndrome to be established. ${ }^{4-6}$

We have used such a complex approach to examine 12 patients with stigmata of Turner's syndrome for precise karyotyping, identification of the origin of marker chromosomes, and determination of the $\mathrm{Y}$ material in these subjects.

\section{Materials and methods}

PATIENTS

All 12 patients reported here are unrelated females with ages ranging from 7 to 32 years. Patient 8 has been previously reported. ${ }^{6}$ The main reasons for their karyotyping were short stature, hypoplasia of the external genitalia, and delayed puberty. Nine of them were subjected to ultrasonographic examination. Laparascopy with subsequent gonadal biopsy or gonadectomy and histological study of the gonads was carried out in four cases. Clinical details of each subject are presented in table 1 .

\section{KARYOTYPING}

Karyotype analysis was performed by standard
FISH TECHNIQUE

The following biotin labelled pericentromeric specific DNA probes were used: pYAM10-40 for the $\mathrm{X}$ chromosome ${ }^{7}$ and $\mathrm{Y} 97^{8}$ and $\mathrm{pHY} 2.1$ 


\begin{tabular}{|c|c|c|c|c|c|c|c|c|c|c|c|c|}
\hline & \multicolumn{12}{|c|}{ Patient } \\
\hline & 1 & 2 & 3 & 4 & 5 & 6 & 7 & 8 & 9 & 10 & 11 & 12 \\
\hline Age (y) & 22 & 32 & 17 & 26 & 20 & 7 & 14 & 14 & 18 & 22 & 19 & 22 \\
\hline $\begin{array}{l}\text { Clinical features } \\
\text { Short stature } \\
\text { Epicanthic folds } \\
\text { Arched palate } \\
\text { Micrognathia } \\
\text { Short neck } \\
\text { Low hairline } \\
\text { Shield chest } \\
\text { Cubitus valgus } \\
\text { Thyroid gland hypertrophy } \\
\text { Mental retardation }\end{array}$ & $\begin{array}{l}+ \\
+ \\
+\end{array}$ & $\begin{array}{l}+ \\
+ \\
+\end{array}$ & $\begin{array}{l}+ \\
+ \\
+ \\
+ \\
+\end{array}$ & $\begin{array}{l}+ \\
+ \\
+ \\
+ \\
+ \\
+ \\
+ \\
+\end{array}$ & $\begin{array}{l}+ \\
+ \\
+ \\
+ \\
+\end{array}$ & $\begin{array}{l}+ \\
+ \\
+ \\
+ \\
+ \\
+ \\
+\end{array}$ & $\begin{array}{l}+ \\
+ \\
+ \\
+ \\
+ \\
+ \\
+ \\
+\end{array}$ & $\begin{array}{l}+ \\
+ \\
+ \\
+\end{array}$ & $\begin{array}{l}+ \\
+ \\
+ \\
+ \\
+\end{array}$ & $\begin{array}{l}+ \\
+\end{array}$ & $\begin{array}{l}+ \\
+ \\
+ \\
+ \\
+ \\
+\end{array}$ & $\begin{array}{l}+ \\
+ \\
+\end{array}$ \\
\hline $\begin{array}{l}\text { External genitalia } \\
\text { Normal female } \\
\text { Hypoplasia }\end{array}$ & + & + & + & + & + & & + & + & + & + & + & + \\
\hline $\begin{array}{l}\text { Gonads } \\
\text { Not detected } \\
\text { Rudimentary } \\
\text { Streak }\end{array}$ & + & & + & + & + & & + & + & + & $\begin{array}{l}\mathrm{L} \\
\mathrm{R}\end{array}$ & + & $\begin{array}{l}\mathrm{L} \\
\mathrm{R}\end{array}$ \\
\hline $\begin{array}{l}\text { Uterus } \\
\text { Hypoplasia } \\
\text { Streak } \\
\text { Double horned }\end{array}$ & & & + & + & + & & + & + & + & + & & $\begin{array}{l}+ \\
+\end{array}$ \\
\hline $\begin{array}{l}\text { Histology } \\
\text { Degenerative follicles } \\
\text { Leydig cells } \\
\text { Wolffian ducts }\end{array}$ & & & & & & & & + & + & & + & + \\
\hline
\end{tabular}

for the $\mathrm{Y}$ chromosome. ${ }^{9}$ The hybridisation procedure was as described elsewhere. ${ }^{10}$ Hybridisation signals were scored both in metaphases and in interphase nuclei (500 cells in total).

\section{PCR ANALYSIS}

DNA samples extracted from peripheral blood lymphocytes by means of conventional proteinase $\mathrm{K}$ method were used for PCR with specific oligoprimer sets corresponding to the $D Y Z 1^{11}$ and $D Y Z 3^{12}$ loci of the Y chromosome. Analysis of the SRY locus was performed by nested PCR with XES2 and XES $7^{13}$ as external primers, and SRY1 and SRY2 ${ }^{14}$ as internal ones.

\section{Results}

The clinical details of the 12 patients analysed are shown in table 1 . All of them showed clear cut short stature and hypoplasia of the genitalia without genital ambiguity. Rudimentary or streak gonads and uteri were registered in nine cases but ultrasonographic examination could not be done in cases 2, 4, and 6. Other Turner's syndrome stigmata included short neck (cases $1,3,4,5,7,8,9,10,11,12$ ), low hairline (cases 5, 9, 11, 12), shield chest (cases 3, 4, 5, $8,9,10$ ), high palate (cases $1,3,4,6,7,9$, $11,12)$, some minor skeletal malformations such as cubitus valgus (cases $1,3,4,5,6,7$, 8,12 ), and micrognathia (cases $2,4,6,7,11$ ). Some of the patients had other clinical stigmata and pathological traits not confined to Turner's syndrome, such as thyroid gland hypertrophy (cases $2,7,8$ ) and mental retardation (case 6). Thus Turner's syndrome stigmata including short stature and underdeveloped, rudimentary, or absent gonads were typical for each of our patients. None of them, however, had other classical Turner's syndrome traits such as webbed neck, congenital heart defects, generalised lymphoedema, aortic coarctation, etc.

Chromosomal analysis of QFH/AcD banded chromosomes (data not shown) ascertained an abnormal karyotype in each of the 12 patients under study with eight of them carrying one rearranged X chromosome (cases 1-8) and five

Table 2 Combined results of cytogenetic and molecular studies of the patients

\begin{tabular}{|c|c|c|c|c|c|c|c|c|c|c|}
\hline \multirow[t]{2}{*}{ Patient } & \multicolumn{4}{|l|}{ Cytogenetic } & \multicolumn{3}{|c|}{ Molecular (PCR) } & \multicolumn{3}{|c|}{ FISH with probe } \\
\hline & Karyotype & $\begin{array}{l}\text { Cell } \\
\text { No* }\end{array}$ & $\begin{array}{l}\text { Replication } \\
\text { of marker }\end{array}$ & $\begin{array}{l}\text { Cell } \\
\text { No† }\end{array}$ & $S R Y$ & $D Y Z 3$ & $D Y Z 1$ & $p Y A M 10-40$ & $Y 97$ & pHY2.1 \\
\hline 1 & 46,X,idic $(X q)$ & 11 & Late & 15 & & ND & & + & ND & ND \\
\hline 2 & $46, \mathrm{X}, \mathrm{i}(\mathrm{Xq})$ & 11 & Late & 20 & & ND & & + & ND & ND \\
\hline 3 & $45, \mathrm{X} / 46, \mathrm{X}, \mathrm{i}(\mathrm{Xq})(50 \%)$ & 20 & Late & 30 & & ND & & + & ND & ND \\
\hline 4 & $45, \mathrm{X} / 46, \mathrm{X}, \mathrm{r}(\mathrm{X})(10 \%)$ & 30 & Early & 50 & - & - & - & + & ND & ND \\
\hline 5 & $45, X / 46, X, r(X)(15 \%)$ & 50 & Early & 50 & - & - & - & + & ND & ND \\
\hline 6 & $45, \mathrm{X} / 46, \mathrm{X}, \operatorname{dicr}(\mathrm{X})(30 \%) / 47, \mathrm{X}, \mathrm{f}(\mathrm{X}), \mathrm{f}(\mathrm{X})(10 \%)$ & 80 & Early & 60 & - & - & - & + & ND & ND \\
\hline 7 & $45, \mathrm{X} / 46, \mathrm{X}, \mathrm{r}(\mathrm{X})(10 \%) / 46, \mathrm{X}, \operatorname{dic}(\mathrm{X})(5 \%)$ & 110 & ND & & - & - & - & + & ND & ND \\
\hline 8 & $46, \mathrm{X}, \mathrm{t}(\mathrm{X} ; \mathrm{Y})$ & 11 & Early & 100 & - & - & + & + & ND & + \\
\hline 9 & $45, \mathrm{X} / 46, \mathrm{X}, \operatorname{der}(\mathrm{Y})(50 \%)$ & 40 & Early & 40 & + & + & - & + & + & - \\
\hline 10 & $45, X / 46, X, \operatorname{idic}(Y p)(40 \%)$ & 50 & Early & 40 & + & + & - & + & + & ND \\
\hline 11 & $45, \mathrm{X} / 46, \mathrm{X}, \operatorname{idic}(\mathrm{Yp})(15 \%)$ & 100 & ND & & + & + & - & ND & + & ND \\
\hline 12 & $45, \mathrm{X} / 46, \mathrm{XYq}-(3 \%)$ & 100 & ND & & + & + & - & ND & + & ND \\
\hline
\end{tabular}

$\mathrm{ND}=$ not done

mosaics (excluding case 12) total cell number analysed was 500 (metaphase plates +interphase nuclei after FISH).

† Metaphase plates with marker. 

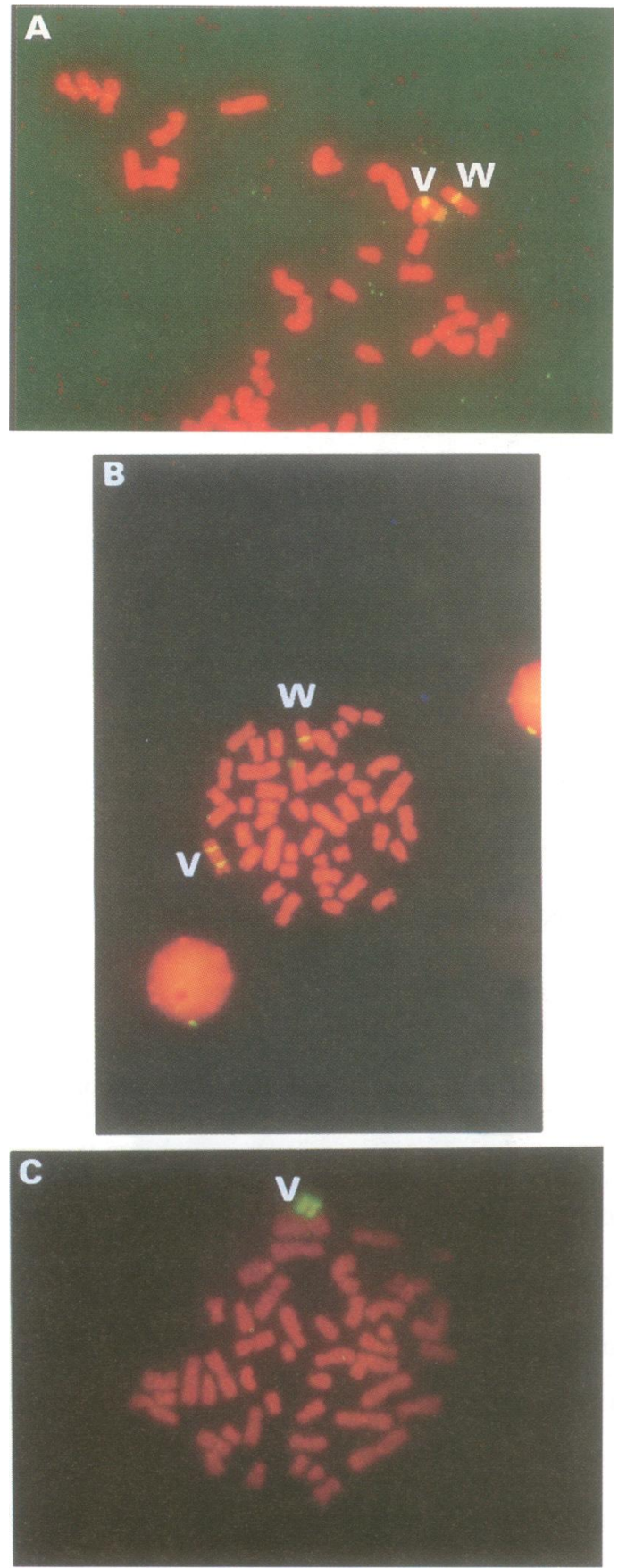

Figure 1 Fluorescent in situ hybridisation of biotin labelled probes pYAM10-40(B), Y97(C) and simultaneously $p Y A M 10-40$ and $p H Y 2.1$ (A) to metaphase chromosomes from $(A)$ patient 8 , (B) patient 7 , and $(C)$ patient 10 (see text and table 2 for details). $V$ indicates the marker chromosomes, $W$ indicates the normal $X$ chromosomes.

of them having $\mathrm{Y}$ chromosome material (cases 8-12). The karyotypes of these patients as well as the results of corresponding FISH and molecular studies are summarised in table 2 .

A single blood lymphocyte line with a $46, \mathrm{X}$, $\operatorname{der}(\mathrm{X})$ karyotype was found in three patients (cases $1,2,8$ ) with two of them bearing $\mathrm{Xq}$ rearrangements, $\mathrm{i}(\mathrm{Xq})$ (case 1 ) and idic $(\mathrm{Xq})$ (case 2), as proved by FISH analysis with alphoid pericentromeric DNA probe pYAM10-40. In the remaining single cell line case (case 8) a Xp22.3;Yq11 translocation was suspected and later proved by FISH with
pYAM10-40 and pHY2.1 DNA probes (fig 1A) as well as by PCR analysis (fig 2, top).

The presence of at least one more chromosomally abnormal line was registered in nine cases (cases 3, 4, 5, 6, 7, 9, 10, 11, 12) and two additional lymphocyte cell lines were identified in cases 6 and 7. The proportions of different cell lines in mosaics scored both in metaphase plates and in interphase nuclei after in situ hybridisation with relevant DNA probes varied from $3 \%$ (case 11 ) to $50 \%$ (case 5) (table 2).

FISH and molecular analyses were undertaken for identification of marker chromosomes in all nine mosaics in whom routine cytogenetic methods had failed to define the origin of small marker fragments. The marker chromosomes in both cases 4 and 5 (data not shown) were small rings bearing $X$ chromosome centromeric regions with no indication of $\mathrm{Y}$ chromosome material (table 2).

A dicentric $\mathrm{X}$ chromosome derivative predominantly of a ring shape was identified in $30 \%$ of cells in case 6 . Two rod shape markers with only one centromere were found in a small proportion of metaphases in the same subject (data not shown).

Three cell lines 45,X/46,X,r(X)/46,X, $\operatorname{dic}(\mathrm{X})$, in proportions $85 \%, 15 \%$, and $5 \%$ respectively, were found in case 7 (fig 1B).

Cases 8 to 12 were proved to bear $\mathrm{Y}$ chromosome material (table 2). One of them (case 8) was non-mosaic, as was reported earlier, while the remaining ones were mosaics with different ratios of $Y$ chromosome fragment cell lines (table 2).

PCR analysis with oligoprimer systems specific for different parts of the $\mathrm{Y}$ chromosome was undertaken to identify the constitution of $\mathrm{Y}$ fragments in the karyotypes of the previous group of patients (table 2). Presence of the DYZ1 locus was found only in case 8 (fig 2, top). Locus DYZ3 corresponding to the pericentromeric region of the $\mathrm{Y}$ chromosome (fig 2, top) as well as the SRY gene (Yp11.3) (fig 2, bottom) were ascertained for the marker chromosomes in cases $9,10,11$, and 12 .

Patients 9 to 12 were positive for the centromeric heterochromatin region, and two of them (case 10, fig $1 \mathrm{C}$; case 11, data not shown) were identified as $\operatorname{dic}(\mathrm{Yp})$ by FISH with the Y97 DNA probe.

Only three metaphases with a small Y chromosome specific centromeric fragment were found in 100 metaphases of case 12 . The presence of this cell line in about $5 \%$ of lymphocyte cells has been proven by FISH studies of interphase cells as well as by PCR analysis of DNA samples of this subject (fig 2).

Replication pattern of marker chromosomes was undertaken for 10 patients. Both $\mathrm{i}(\mathrm{Xq})$ (cases 2 and 3 ) and idic $(\mathbf{X q})$ (case 1) were late replicating while the $\mathrm{X} ; \mathrm{Y}$ translocation product in case 8 showed a preferential early pattern of replication (data not shown) in more than $90 \%$ of metaphase cells scored (table 2). The ring (X)s (cases 4 and 5) including $\operatorname{dicr}(\mathrm{X})$ (patient 6) were found to be early replicating after BrdU staining (fig 3 ) in all cells in which they were present (table 2). 

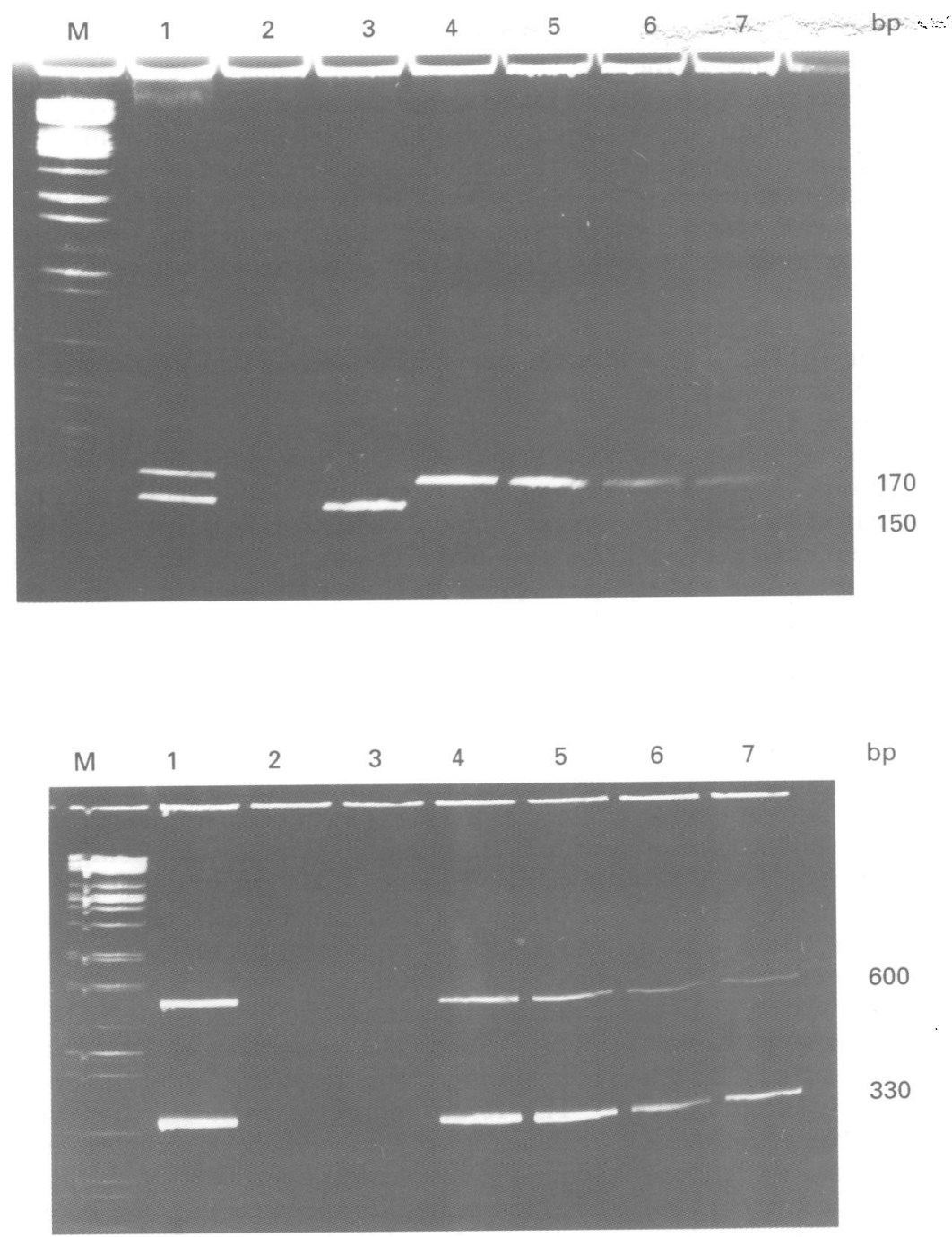

bp

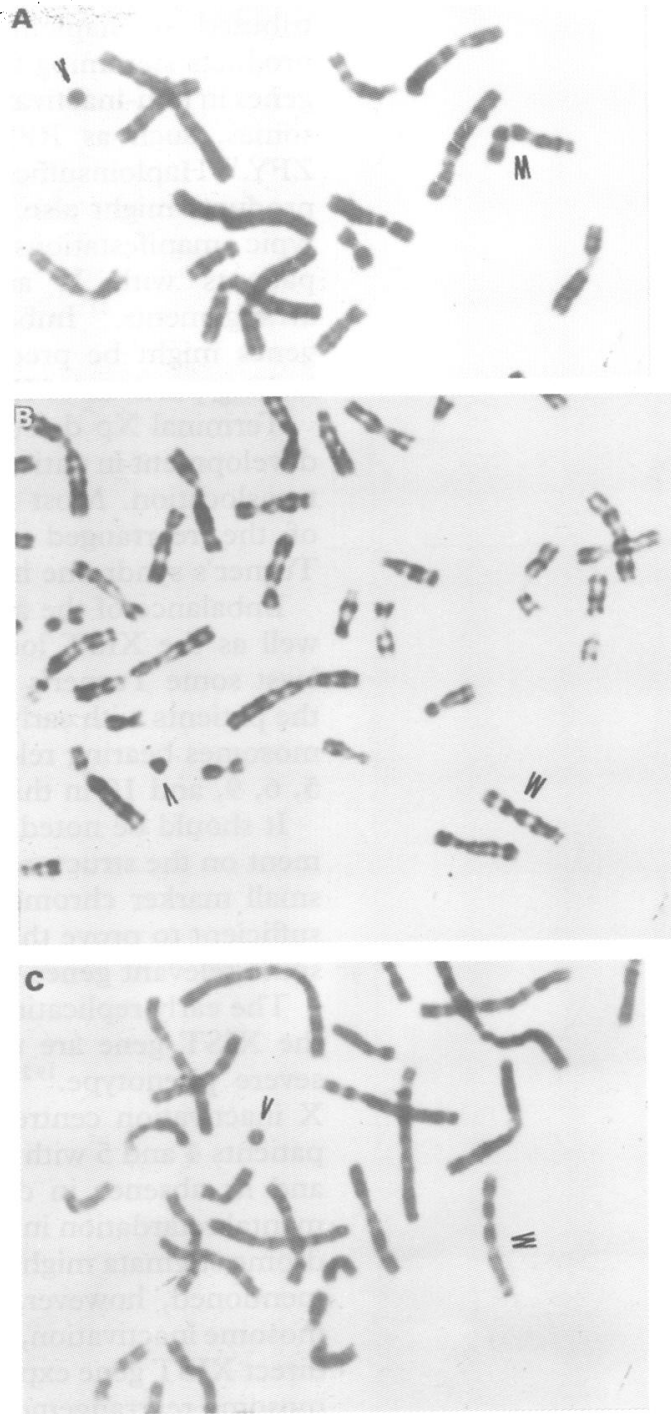

Figure $2 Y$ chromosome specific sequences amplified by PCR with oligoprimers

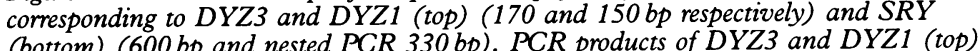
and both fragments of SRY (bottom) were electrophoresed together. Lane $M: D N A$ digested with PstI (size marker); lanes 1-7: peripheral blood DNA from control male lane 1), control female (lane 2), and patients 8 (lane 3), 9 (lane 4), 10 (lane 5), 11 (lane 6), and 12 (lane 7).

Early replicating Y chromosome marker derivatives were determined in two patients (cases 9 and 10) (data not shown).

This study has not yet been performed in cases 7,11 , and 12 (table 2).

\section{Discussion}

Two basic hypotheses on the manifestation of Turner's syndrome can be considered; first, the existence of two $\mathrm{X}$ chromosomes for the survival of early human XO conceptuses, ${ }^{1516}$ and, second, haploinsufficiency or imbalance of some gene products in non-activated homologous regions of the $\mathrm{X}$ and $\mathrm{Y}$ chromosomes. ${ }^{17-20}$

It is well known that over $90 \%$ of all $\mathrm{XO}$ conceptuses are eliminated during early prenatal development and chromosomal mosaicism, involving both $\mathrm{X}$ and $\mathrm{Y}$ chromosomes, has often been found in Turner's syndrome patients postnatally. ${ }^{51521}$ According to the present findings nine of 12 patients studied were found to be mosaics with at least one chro-
Figure 3 Replication patterns of the $X$ and ring $(X) s$ from PHA stimulated lymphocytes of patient $4(A), 5$ $(B)$, and $6(C)$. Both the ring $(V)$ and the normal $X$ chromosome $(W)$ are early replicating after $B r D U$ incorporation for the last six hours of culturing following FPG staining.

mosomally abnormal cell line bearing $\mathrm{X}$ or $\mathrm{Y}$ chromosome fragments. The presence of a second aberrant cell line was registered in three cases only, with two of them being represented by an abnormal $\mathrm{i}(\mathrm{X})$ chromosome and one by an $\mathrm{Xp} ; \mathrm{Yq}$ translocation product. Thus, a definite proportion of chromosomally abnormal cells in each patient studied contained a double dose of chromosomal material of both gonosomes. In view of the present hypothesis the existence of genetic material of two identical $(\mathrm{X} / \mathrm{X})$ or heterologous $(\mathrm{X} / \mathrm{Y})$ chromosomes could be sufficient to allow survival of the relevant conceptuses during early embryogenesis when genetic activity of some homologous loci on both gonosomes are required for normal development. ${ }^{1521}$ Our data are thus in line with the hypothesis of proven or cryptic chromosomal mosaicism as indispensable for successful survival of XO conceptuses.

None of our patients showed a classical pattern of Turner's syndrome and some of them had pathological traits of other inherited disorders. Some of these findings could be at- 
tributed to haploinsufficiency of the gene products stemming from the imbalance of the genes in non-inactivated portions of both gonosomes, such as RPS4X/RPS4Y ${ }^{17}$ and ZFX/ ZFY. ${ }^{18}$ Haploinsufficiency of some other gene products might also contribute to the phenotypic manifestations in Turner's syndrome patients with $\mathrm{X}$ and $\mathrm{Y}$ chromosome rearrangements. ${ }^{22}$ Imbalance of these particular genes might be predicted in all our patients lacking portions of Xp22.3 or Yp11.2.

Terminal $\mathrm{Xp}$ deletion resulted in abnormal development in patient 8 with an Xp22.3;Yq11 translocation. Most probably the active state of the rearranged chromosome resulted in Turner's syndrome in this particular case. ${ }^{6}$

Imbalance of the above mentioned genes as well as the XIST locus might account for at least some Turner's syndrome stigmata ${ }^{2324}$ in the patients with early replicating marker chromosomes bearing relevant fragments (cases 4 , $5,6,9$, and 10 in this report).

It should be noted that a cytogenetic judgement on the structure and replication status of small marker chromosomes is far from being sufficient to prove the presence and activity of some relevant genes (see above).

The early replicating small ring (X)s lacking the XIST gene are usually associated with a severe phenotype. ${ }^{192324}$ The presence of the $\mathrm{X}$ inactivation centre (XIST) in ring (X)s in patients 4 and 5 with a mild Turner phenotype and its absence in $\operatorname{dicr}(\mathrm{X})$ in patient 6 with mental retardation in addition to Turner's syndrome stigmata might be possible. It should be mentioned, however, that failure of $\mathrm{X}$ chromosome inactivation, as might be inferred from direct XIST gene expression studies in X chromosome rearrangements, does not explain the severe phenotype of affected patients. ${ }^{25}$

Conspicuous clinical polymorphism in each of our patients justifies more precise identification of chromosome breakpoints for better understanding of developmental effects caused by the structural chromosomal imbalance.

Sizes and frequencies of rearranged marker chromosomes might also contribute to the phenotypic diversity. ${ }^{23}$ The latter might also be attributed to substantial variability of each genetically abnormal cell line in different tissues. ${ }^{1526}$ Analysis of mosaic cell lines in blood lymphocytes is hardly applicable for the proper estimation of the cell proportion with an abnormal karyotype in the other tissues. This could be the explanation in case 12 with a very small proportion of Yp fragment bearing cells (3\%) in blood but with definite Leidig cells in her rudimentary gonads.

The basic sex determining factor responsible for switching on male development is known as the SRY gene, located in Yp11.2 very close to the pseudoautosomal region of this chromosome. ${ }^{27}$ According to recent data, the regulatory gene responsible for switching to the female pathway of sex differentiation is mapped to $\mathrm{Xp} 21.1-21.3^{28-30}$ Some other autosomal genes are also suspected to be involved in phenotypic sex differentiation as well. . $^{11-33}$

All our patients were female on external examination. Underdevelopment of the ex- ternal genitalia and gonads in all subjects with $\mathrm{X}$ chromosome aberrations (cases 1-7) might be attributed to the same still unknown mechanisms which are responsible for primordial germ cell elimination and development of streak gonads in the patients lacking one $\mathrm{X}$ chromosome. It is possible that early replication of Xq chromosomal fragments bearing RPS4X, ZFX, and XIST genes in the absence of an ovarian differentiation gene mapped to Xp21 could not provide normal development of female genitalia in these cases.

A female phenotype in all our subjects bearing $\mathrm{Y}$ material is a more difficult task for adequate interpretation. No SRY gene was found in case 8 and thus her female phenotype might be attributed to the absence of a regulatory SRY gene product. Both SRY fragments screened by PCR were discovered in four other female patients with cytogenetically and molecularly proven $\mathrm{Y}$ chromosome cell lines. Typical Leydig cells and rudimentary seminiferous tubules were found in histological sections of gonads in three of them (cases 9, 11, and 12). The reason for the femaleness in these patients with Y chromosome cells remains completely obscure. Whether their phenotype could be attributed to some inefficiency of SRY as a transcriptional repressor or whether its activity has been disrupted by two doses of active ovarian differentiation genes in $\mathrm{Xp} 21.1-$ $21.3^{28-30}$ or by the proportion of $\mathrm{Yp}$ positive cells in different tissues needs to be clarified.

The results of the present study provide evidence for the importance of complex cytogenetic and molecular approaches in the identification of marker chromosomes and precise analysis of $\mathrm{X}$ and $\mathrm{Y}$ chromosomes aberrations. Each of these methods has its own advantages and drawbacks which should be carefully considered before application. Classical cytogenetic methods provide more general information on karyotype structure and chromosomal rearrangements but are hardly applicable for marker chromosome identification or exact breakpoint location. The former might be much more easily attained with FISH, while the latter goal might be readily achieved by DNA analysis, which is more rapid, precise, and efficient. Meanwhile both FISH and DNA analysis have their own limitations and rely on the knowledge of karyotype structure and rearrangements for precise identification.

It should be pointed out, however, that application of the FISH technique in mosaic cases with a small number of abnormal cell lines (case 12) is not of great diagnostic value as the specific labelling signals are very difficult to discriminate from the background level. The same is true for the SRY gene analysis by standard PCR in mosaics with a very low proportion of $\mathrm{Y}$ positive clones (too faint specific amplification bands in cases 11 and 12) (fig 2 , bottom). Application of PCR with nested oligoprimers has helped to solve this problem.

We are convinced by the present results, as well as by data of other authors, ${ }^{42134}$ that only the combined application of cytogenetic and molecular techniques can enable adequate chromosomal analysis in patients with marker 
chromosomes or with complex chromosome rearrangements.

We would like to thank Dr D K Verlinskaya and the clinicians I Vasilkova and L Sandomirskaya (The Medical Genetical Centre, St Petersburg) for providing us with medical records of patients, and the pathologist O A Dobrotvortzeva (Inst Obst Gynec, St Petersburg) for information on gonadal histology. Wyec, St Petersburg) for information on gonadal histology. We are especially indebted to Professor Nico Leschot (Inst reagents, critical reading of the manuscript, and valuable comreagents,

1 Gicquel C, Cabrol S, Schneid F, Le Bouc Y. Molecular diagnosis of Turner's syndrome. 7 Med Genet 1992;29. diagnosis

2 Dyban AP, Baranov VS. Cytogenetics of mammalian embryonic development. Oxford: Oxford University Press, 1987.

3 Page DC. Y chromosome sequences in Turner's syndrome. Lancet 1994;343:240.

4 Petrovic V, Nasioulas S, Chow CW, Voullaire L, Schmidt M, Dahl H. Minute Y chromosome derived marker in a child with gonadoblastoma: cytogenetic and DNA studies. f Med Genet 1992;29:542-6.

5 Nagafuchi S, Tamura T, Nakahori Y, et al. The majority of the marker chromosomes in Japanese patients with stigmata of Turner's syndrome are derived from Y chromosomes. Hum Genet 1992;89:590-2.

6 Kuznetzova T, Baranov A, Ivaschenko T, et al. X;Y translocation in a girl with short stature and some features of Turner's syndrome: cytogenetic and molecular studies. $\mathcal{f}$ Med Genet 1994;31:649-51.

7 Alexandrov IA, Yurov YB, Mitkevitch SP, Gindilis VM Chromosomal localization of alphoid DNA in man. Dokl Acad Nauk USSR 1986;288:242-5.

8 Wolfe JJ, Darling SM, Erickson RP, et al. Isolation and characterization of an alphoid centromeric repeat family from the human Y chromosome. $7 \mathrm{Mol} \mathrm{Biol} \mathrm{1985;182}$ 477-85.

9 Cook HI, Schmidtke I, Gosden IR. Characterization of a Y-chromosome repeated sequence and related sequences in higher primates. Chromosome 1982;87:491-502.

10 Pinkel D, Straume T, Gray JW. Cytogenetic analysis using quantitative, high-sensitivity, fluorescence hybridization. Proc Natl Acad Sci USA 1986;83:2934-8.

11 Kogan SC, Doherty M, Gitschier J. An improved method for prenatal diagnosis of genetic diseases by analysis of amplified DNA sequences. Application to hemophilia A. N Engl f Med 1987;317:985-90.

12 Witt M, Erickson RP. A rapid method for detection of Y-chromosomal DNA from dried blood specimens by polymerase chain reaction. Hum Genet 1989;82:271-4.

13 Berta P, Hawkins JR, Sinclair AH, et al. Genetic evidence equating SRY and testis determining factor. Nature 1990; 348:448-50.

14 Koopman P, Gubbay J, Vivian N, Goodfellow P, LovellBadge R. Male development of chromosomally female mice transgenic for SRY. Nature 1991;351:117-21.

15 Held KR, Kerber S, Kaminsky E, et al. Mosaicism in 45, $\mathrm{X}$ Turner syndrome: does survival in early pregnancy depend on the presence of two sex chromosomes? Hum Genet 1992;88:288-94.
16 Hassold T, Pettay D, Robinson A, Uchida I. Molecular studies of parental origin and mosaicism in $45, \mathrm{X}$ conceptuses. Hum Genet 1992;89:647-52.

17 Fisher EM, Beer-Romero P, Brown LG, et al. Homologous ribosomal protein genes on the human $\mathrm{X}$ and $\mathrm{Y}$ chromosomes: escape from $\mathrm{X}$ inactivation and possible im plications for Turner syndrome. Cell 1990;63:1205-18.

18 Ogata T, Tyler-Smith C, Purvis-Smith S, Turner G. Chromosomal localization of a gene(s) for Turner stigmata on Yp. F Med Genet 1993;30:918-22.

19 Migeon BR, Luo S, Stasiowski BA, et al. Deficient transcription of XIST from tiny ring $\mathrm{X}$ chromosomes in females with severe phenotypes. Proc Natl Acad Sci USA 1993;90:12025-9.

20 Ballabio A, Carrozzo R, Fil A, et al. Molecular characterization of human $\mathrm{X} / \mathrm{Y}$ translocations suggests their aetiology through aberrant exchange between homologous sequences on Xp and Yq. Ann Hum Genet 1989;53:9-14

21 Ostrer H, Clayton CM. Y chromosome mosaicism in 45, X Turner syndrome. Am 7 Med Genet 1989;34:294-6.

22 Ogata T, Goodfellow P, Petit C, Aya M, Matsuo N. Shor stature in a girl with a terminal $\mathrm{Xp}$ deletion distal to DXS15: localization of a growth gene(s) in the pseudoautosomal region. 7 Med Genet 1992;29:455-9.

23 Callen DF, Eyre HJ, Dolman G, et al. Molecular cytogenetic characterization of a small ring $X$ chromosome in a Turner patient and in a male patient with congenital abnormalities: role of X inactivation. F Med Genet 1995;32:113-6.

24 Lingren V, Chen C, Bryke CR, Lichter P, Page DC, YangFeng TL. Cytogenetic and molecular characterization of marker chromosomes in patients with mosaic 45 , X karyotypes. Hum Genet 1992;88:393-8.

25 Dennis NR, Collins AL, Crolla JA, Cockwell AE, Fisher AM, Jacobs PA. Three patients with ring (X) chromosomes and severe phenotpe. $\mathcal{F}$ Med Genet 1993;30:482-6.

26 Diekmann L, Palm K, Pfeiffer RA, et al. Multiple minute marker chromosomes derived from Y identified by FISH in an intersexual infant. Hum Genet 1992:90:181-3.

27 Sinclair AH, Berta P, Palmer MS, et al. A gene from the human sex-determining region encodes a protein with
similarity to a conserved DNA binding motif. Nature 1990; similarity to a

28 Ogata T, Hawkins JR, Taylor A, Nobutake M, Hata J, Goodfellow PN. Sex reversal in a child with a $46, X, Y p+$ karyotype: support for the existence of a gene(s), located in distal $\mathrm{Xp}$, involved in testis formation. $\mathcal{f}$ Med Genet 1992;29:226-30.

29 Ogata T, Matsuo N. Testis determining gene(s) on the $\mathrm{X}$ chromosome short arm: chromosomal localization and possible role in testis determination. 7 Med Genet 1994; 31:349-50.

30 Bardoni B, Zanaria E, Guioli S, et al. A dosage sensitive locus at chromosome $\mathrm{Xp} 21$ is involved in male to female sex reversal. Nature Genet 1994;7:497-501.

31 Bennet CP, Docherty Z, Robb SA, Ramani P, Hawkins JR, Grant D. Deletion 9p and sex reversal. $₹$ Med Genet 1993; 30:518-20.

32 Kennerknecht I, Sorgo W, Oberhoffer R, et al. Familial occurrence of agonadism and multiple internal malformations in phenotypically normal girls with $46, \mathrm{XY}$ and 46,XX karyotypes, respectively: a new autosomal recessive syndrome. Am 7 Med Genet 1993:47:1166-70.

33 McElreavy K, Vilan E, Abbas N, Herskowitz I, Fellow $\mathrm{M}$. A regulatory cascade hypothesis for mammalian sex determination: SRY repress a negative regulator of male development. Proc Natl Acad Sci USA 1993;90:3368-72.

34 Cheng SD, Gasparini R, Muller U. Molecular analysis of aberrations of Xp and Yq. Hum Genet 1992;88:379-82. 